DOI https://doi.org/10.32838/2663-6069/2019.sp.21

\section{Жерар Абенсур}

Эколь Нормаль Супериор (Лион, Франция)

\section{Н. А. ОЦУП ${ }^{1}$}

Мне показалось интересным обратиться к судьбе одной личности, чей путь довольно типичен для представителей русской интеллигенции. После революции 1917 г. Николай Авдеевич Оцуп постепенно охладевает к новому строю, в 1922 г. решает покинуть родину и стал эмигрантом. До эмиграции он был подающим большие надежды поэтом, учеником Николая Гумилева. Как и его учитель, Н. С. Гумилев, Н.А. Оцуп никогда не проявлял какого-либо интереса к политике или к идеологическим дискуссиям.

Когда в 1930 г. Н. Оцуп создал в Париже журнал под названием "Числа», он думал о сугубо литературном журнале, очень важном в тот момент, когда решался вопрос о дальнейшем существовании русской эмигрантской литературы в иностранной среде. Поэт не может не заботиться о судьбе его сокровища, его оружия, - о родном языке. В 1930-х гг. русская интеллигенция во Франции считала, что её миссия состоит в том, чтобы сохранить чистоту языка и защищать его как от контаминации с французской культурой, так и от советизации русского языка на родине.

Как станет видно, сложная судьба Оцупа (1894 - 1958)сочетает в ceba поэта, издателя и «проводника» родного языка во второй родине.

Семья Оцупов была талантливой и одаренной. Дети, их было шестеро, учились в Николаевской Царскосельской гимназии и закончили ее с отличием. Николай Авдеевич был пятым ребенком в семье. Уже в ранней юности он стал писать стихи и благоговел перед поэтом Иннокентием Федоровичем Анненским, бывшим директором Царскосельской гимназии.

Трое сыновей занимались поэзией: кроме Николая, который стал учеником Николая Гумилева в 1918 г, стали сочинять стихи и старший брат Александр, инженер по профессии, писавший под псевдонимом Сергей Горный, и младший брат Георгий, выбравший псевдоним Георгий Раевский. Интересно, что последний из детей, Надежда Авдеевна, которой исполнилось 16 лет в 1917-м году, стала сотрудничать с ЧК.

${ }^{1}$ Н. А. Оцуп, поэт-акмеист, бывший член «Цеха поэтов» (Петроград, 1917-1922), впоследствии - главный редактор журнала «Числа» (Париж, 1930-1934): штрихи к биографии
После окончания гимназии с отличием Николай Авдеевич заложил за 32 рубля золотую медаль и уехал в Париж. Он провел в Париже год (1913 г.) и посещал курсы в Сорбонне, где он слушал лекции знаменитого философа Анри Бергсона. Когда началась Первая мировая война, Н. А. Оцуп вынужден был прервать свое пребывание во Франции.

В 1916 г он был призван в армию. «Петербург (sic) и казармы, запасной полк, 5-ая Армия и снова Петербург уже с красными флагами, ошалевшими броневиками, мне стало явно, что надо заниматься серьезно своим делом. Стал работать в издательстве "Всемирная литература».

Как он воспринял февральскую революцию? Пока у меня нет на этот счет точных сведений.

Как только стало известно об отречении императора Николая II от престола, была изложена программа первоочередных преобразований: амнистия по политическим и религиозным вопросам, свобода слова, печати и собраний, отмена сословий и ограничений по религиозным и национальным признакам, замена полиции народной милицией, выборы в органы местного самоуправления. Фундаментальные вопросы - о политическом строе страны, аграрной реформе, самоопределении народов - предполагалось решить уже после созыва Учредительного собрания. Разрушилась кажущаяся незыблемой власть, самодержавие. Вдруг проявилась долгожданная « свобода». Но для большинства народа это означало «воля», что существует свобода необузданная, не подчиненная закону. Это основное недоразумение привело к провалу демократическую Республику.

Тонкий наблюдатель русской действительности, Пьер Паскаль, служивший тогда во французский военной миссии, так описывал атмосферу в Петрограде в своем дневнике:

«После того, как прошли решительные дни, изменился уличный спектакль. Можно было видеть праздную толпу, всегда готовую окружать самозваного оратора. Наконеи, можно было говорить обо всем свободно, и каждый наслаждался, выслушивая неимоверное количество речей, мнений, присутствуя на самых разных совещаниях. Ничто больще не ограничивало право собраний. 
Обшуая атмосфера была добродушная, полная оптимизма, несмотря на внезапное появление какого-нибудь фанатика из той или иной партии. Считалось, что война скоро кончится, раз революция ужсе совершилась. Но иногда появлялся какойнибудь разумный человек, доказывавший, что все это - только иллюзии, и начинались дискуссии».

Первым делом стали возвращаться репатрианты, те, кто покинул Россию, чтобы избежать преследований со стороны царской охранки и ареста. Так, вернулись из-за заграницы или с каторги те, кто боролся с царским режимом, будь то социалисты-революционеры (эсеры); социал-демократы (большевики и меньшевики); толстовцы. Для тех, кто не был на каторге или в ссылке, было сравнительно легко «отправиться путем зеленой границ». Февральская революция открыла как лидерам, так и рядовым революционерам, возможность возвращения на родину. Поэт Александр Блок осознавал всю сложность этой неожиданной ситуации. 15 Мая он написал в своей записной книжке: «Мне уютно в этой мрачной и одинаковой бездне, которой имя - Петербург 17 года, Россия 17 года».

Свобода слова заметно повлияла на развитие искусства. В Камерном театре была поставлена пьеса Оскара Уайльда «Саломея», которая была дотоле запрещена духовной цензурой.

Какова роль интеллигенции в новых обстоятельствах? Блок задает фундаментальный вопрос: «Волею судьбы (...) я художник, т.е. свидетель. Нужен ли художник демократии?».

После прихода к власти большевиков в Октябре ситуация кардинально меняется. Больше нет и речи о свободе печати или демонстраций. Соответственно, одними из первых эмигрировали журналисты. Они находили приют в одном из многочисленных русских периодических изданий, которые создавались во всем мире (общим количеством 500 с лишним).

Хотя русские после Октябрьской революции эмигрировали в самые разные страны, включая Китай, большая часть русских эмигрантов нашла приют именно во Франции и в особенности в Париже. По разным данным, количество русских эмигрантов во Франции достигало миллиона человек.

В двадцатых годах насчитывается во Франции три ежедневных русских газеты: «Возрождение», «Последние новости» и «Звено» и несколько толстых журналов: «Иллюстрированная Россия», «Современные записки», «Воля России».

Новое правительство относилось к интеллигенции противоречиво. С одной стороны, оно, по большей части, запрещало уезжать за границу тем, кто обратился с этой просьбой (разрешения на выезд добывались с огромным трудом). С другой стороны, осенью 1922 г. было принято решение избавиться от самых ярких представителей русской интеллигенции. Около двухсот видных ученых, писателей, мыслителей с семьями были выдворены из России на так называемых «философских пароходах», причаливших в Германии. Можно считать, что это решение было принято вслед за трагическими событиями, расшатавшими новое государство: восстаниямикронштадтских моряков и тамбовского крестьянства.

С начала 1918 г. в Петрограде и Москве царил голод. Благодаря ходатайству М. Горького, открылись специальные заведения для писателей, поэтов и ученых: Дом ученых, Дом искусств, Дом литераторов. Интеллигенция выживала.

В Доме литераторов собирались члены «Третьего цеха поэтов» во главе с Николаем Гумилевым. Принимали участие в нем, кроме Николая Оцупа, Георгий Адамович, Георгий Иванов, Михаил Лозинский. Оцуп готовил свой первый сборник стихов «Град», который был опубликован в 1921 г. издательством «Цех поэтов». Гумилев читал доклады о литературе, в том числе в Кронштадте, для моряков Балтфлота.

Со своей стороны, Валерий Брюсов стал активно служить новому режиму. Он стал во главе «подотдела учета и регистрации при отделе для обеспечения типографических работ». Фактически это означало, что В. Я. Брюсов мог действовать как цензор.

А Николай Оцуп? Он старался отгородиться от бытовой стороны жизни, не замечать ее. В доказательство этому можно привести строки, написанные в 1918 г. Здесь Оцуп изображает себя в деревне, на лоне природы, далеко от голодного и холодного Петрограда. Он чувствует себя отделенным от мирской суеты:

Проснулся на душистом сеновале...

Уже три дня я ничего не помню

О городе и об эпохе нашей,

Которая покажется, наверно,

историку восторженному эрой

Великих преступлений и геройств.

В самом деле, Оцуп часто уезжал из Петрограда, чтобы достать продукты для себя и своих коллег из Дома Искусств. Корней Чуковский приводит забавный рассказ: «Когда Блок впервые услышал его имя, он спросил у меня, что такое ОЦУП, очевидно, полагая, что это -аббревиатура какого-нибудь учреждения. Я ответил, что, 
насколько я знаю -это Общество Целесообразного Употребления Пищи».

Чуковский объясняет, что «Оцуп был замечателен тем, что временами исчезал их столицы и, возвратившись, привозил откуда-то из дальних краевтакие драгоценности, как сушеная вобла, клюква, баранки, горох, овес, а порой - это звучало как чудо - двадцать или тридцать кусков сахару...».

В 1921 году Анатолий Луначарский с помощью Максима Горького добивался от Ленина разрешения на отъезд за границу для Александра Блока, страдавшего от болезни, которую трудно было лечить в России. Вот, например, что пишет по этому поводу М. Горький:

«У Александра Александровича Блока - цинга, кроме того, за последние дни он в таком нервозном состоянии, что его близкие, а также и врачи опасаются возникновения серьезной психической болезни. И участились припадки астмы, которой он страдает давно уже. Не можете ли Вы выхлопотать - в спешном порядке - для Блока выезд в Финляндию, где я мог бы помочь ему устроиться в одной из лучших санаторий?».

Но представители ЧК возражали против того, чтобы разрешить А. Блоку и его семье выехать за границу.

«Не представляет никакого сомнения, что огромное большинство артистов и художников, выезжающих за границу, являются потерянными для Советской России, по крайней мере, на ближайшие годы.

Когда Блок получил в конце концов разрешение уехать за границу, было слишком поздно. 8-го августа 1921 г. поэт умер, мучительно страдая. Н. Оцуп боготворил Блока. Он был одним из тех, кто нес на своих руках гроб А. Блока на кладбище.

Блока гроб я подпирал плечом

В иеркви наСмоленском крышку сняли.

Я склонился над его лицом:

Мучеников так изображали

На безжалостных полотнах:нос

Желтый, острый, выступили скулы (...)

Человек сгорел, а нес в себе

Музыку небесную ... [1]

Через несколько дней Оцуп претерпевает второй удар. Гумилев арестован и обвинен в контрреволюционном заговоре. Н. Оцуп хлопотал за учителя (вероятно, с помощью своей сестры Надежды, сотрудницы ЧК). Но безуспешно. Гумилев был расстрелян 24-го августа 1921 г. Это, конечно, была последняя капля: еще в январе 1920 г. младший брат Николая Авдеевича был расстрелян сотрудниками ЧК.
Несколько лет спустя Николай Оцуп выразил в «Дневнике в стихах » боль, испытанную после расстрела брата Павла, невинного ученого-лингвиста:

«Брат мой Павлик, а твои где кости? (...)

Вот и Бодуэн де Куртенэ...

На него с пучком цитат латинских

Мчится Павлик, верный ученик (...)

Где писавший по-санскритски

Дважды или трижды медалист?

Муза, плачь !».

Стало очевидно, что нельзя жить нормальной жизнью в условиях нового режима. Как и остальные его товарищи по Цеху поэтов, Оцуп принял решение отдаляться от неузнаваемой страны. Пользуясь своей должностью переводчика с немецкого языка, Оцуп добыл у Горького командировку в Германию. Официальной целью такой командировки был поиск немецких книжных новинок для издательства «Всемирная Литература».

Оцуп очутился в Берлине, который являлся тогда крупным центром русской эмигрантской литературы. В Берлине Оцуп сразу взялся за дело и зимой 1922-23 гг. возобновил «Цех поэтов». С помощью Г. Иванова были переизданы сборники стихов самого Г. Иванова и Оцупа, петроградские альманахи «Цеха поэтов» и выпущен четвертый, берлинский. В следующем сезоне «Цех поэтов» возобновил свою деятельность уже в Париже.

Второй сборник стихотворений Оцупа «Дым», изданный в Берлине в 1926 г, отличался уходом от акмеизма и тяготением к неоклассицизму.

В начале тридцатых годов ситуация в эмиграции существенно изменилась. Как пишет сам Оцуп «Двенадцать лет эмиграции составляют, если не по измерениям истории, то, во всяком случае, для каждой отдельной человеческой жизни, период достаточно длительный». Несмотря на ряд попыток военных кругов свергнуть большевистский режим в России, все уже понимают, что эмиграция становится постоянной.

Как быть тем русским, кто живет за границей, и в данном случае - во Франции? Остаться верными своей родине или же считать Францию своей второй родиной? Это в особенности касалось тех молодых поэтов, которые начали публиковаться на русском языке, но уже только для эмигрантского читателя.

Как было сказано выше, уже существовало четыре толстых русских литературных журнала во Франции. Но Оцуп остро переживал тяжелую раздвоенность русской литературной эмиграции. 
Для этого он задумал создать чисто литературный журнал, открытый для всех поколений писателей, какой бы ни была их политическая позиция.

Элегантно оформленный, этот журнал, под названием « Числа », во многом походил на периодические издания начала века и предлагал читателям подборку прозаических и поэтических произведений, созданных в эмиграции. К произведениям художественной литературы были добавлены критические статьи, посвященные тем или иным произведениям на русском языке, а также современной французской литературе. Каки « Аполлон »,этот журнал был богато иллюстрирован. Многочисленные вклеенные иллюстрации представляли лучшие произведения современных художников, как русских (Зинаида Серебрякова, Сергей Шаршун или Константин Терешкович), так и французских (в основном, художниковимпрессионистов).

Хотя «Числа» были оформлены по модели «Аполлона», дух и тональность этого издания сильно отличались от духа и тональности его предшественника.Различие в названии само по себе показательно. Вместо светлого бога искусства и гармонии из греческой мифологии новый журнал отсылает к библейской традиции.

«Числа» - это русский перевод одной их книг Пятикнижия, название которой на иврите означает «в пустыне». Как и еврейский народ, русская эмиграция «сталкивается со всеми испытаниями земной жизни, в пустыне она приобретает опыт сомнения, бунтарства, но также и надежды». Последним объясняется название новорожденного журнала: «Числа».

В первом номере журнала «Числа» выбор авторов поражает своей умеренностью. Доля молодого поколения довольно скромная- как среди стихотворцев, так и среди прозаиков. В отделе поэзии представлены только два молодых автора молодого поколения, Анатолий Ладинский и Борис Поплавский, тогда как опубликовано шесть стихотворений (стр, 9-28) поэтов старшего и среднего поколения - Зинаиды Гиппиус, Георгия Адамовича, Георгия Иванова и самого Николая Оцупа.

В отделе прозы (стр, 29-135) выбор более пестрый: Гайто Газданов, Ирина Одоевцева, Юрий Фельзен и Сергей Шаршун. Кроме этого, в журнале были размещены две случайных статьи: заметки Сергея Горного (Александра Оцупа) «О фотографии» и рассказ Ирмы де Манциарли о путешествии в Индию.

Богатая женщина, дочь одного из бывших владельцев украинских шахт, г-жа Ирма де Ман- циарли выступила в качестве мецената. После выхода в свет четвертого номера журнала она прекратила финансовую помощь Оцупу, который, с большим трудом,продолжил выпускать журнал, вплоть до десятого номера, вышедшего в 1934 г.

После литературной части мы находим серьезные критические статьи (стр. 136-217). Сам Николай Оцуп пишет исследование о Тютчеве. Остальные страницы журнала содержат рецензии на недавно вышедшие книги. В выборе книг для рецензентов нет ограничений. Здесь можно найти и русские книги, изданные в Берлине или Париже, и книги из Советского Союза, и французские издания. Приведем короткий анализ программной статьи Оцупа, за подписью «Редакция».

Автор статьи настаивает на том, что журнал не будет заниматься политикой, то есть, не будет касаться вопроса об отношении к Советскому Союзу:

«Числа» должны, конечно, иметь ясное, недвусмысленное и твердое отношение к тому, что происходит в Советской России. Наша связь с эмиграцией не только в том, что сами мы эмигранты, эта связь - в разделении нами всех ее задач, но в сборниках не будет места политике, чтобы вопросы сегоднящней минуты не заслоняли других вопросов, менее актуальных, но не менее значительных».

Оцуп ссылается на русскую традицию. В России литература сама по себе всегда играет политическую роль:

«По тем или иным причинам, в русской культуре, как она развивалась в 19 и 20 в.в., почти вся тяжестью самых ответственных вопросов и решений легла на писателей и поэтов (...) Литература в России всегда была проводником ко всем областям жизни (...) Вот почему и вот в каком смысле «Числа» задуманы, как сборники по преимуществу литературные.»

Журнал должен показать, что русская литература, русская культура способны продолжать свое существование и даже развиваться на чужой почве. Одновременно русская эмигрантская культура способна приблизиться к богатой культуре Европы.

Как пишет редактор: «За это время мы многое увидели на западе, мы поняли и почувствовали его иначе, нежели наши предшественники. (...) Мы присутствуем при непрерывном впитывании Европой каких-то русских влияний и сами, каждый по мере сил, в какой-то, может быть еле ощутимой, но все же несомненной степени этому помогаем». 
Для Поплавского «Числа» правильно отражали новые веяния эмигрантской жизни: "Числа,,. есть атмосферическое явление, почти единственная «атмосфера безграничной свободы », где может дышать новый человек, и он не забудет её даже в России». Эти слова были опубликованы в последнем номере журнала. В 1934 г., с глубокой скорбью, Оцуп вынужден был закрыть «Числа».

После долгих скитаний, в особенности в годы Второй Мировой войны, Николай Авдеевич нашел отдушину в педагогической деятельности, о которой он вряд ли бы подумал, если бы его не подтолкнули к ней французские друзья-ученые. После защиты докторской диссертации, посвященной жизни и творчеству Николая Гумилева, Н. Оцуп получил пост преподавателя в Эколь Нормаль Сюпериер, знаменитом парижском высоком учебном заведении, в котором он занимался с аспирантами. Он с радостью встречал молодых студентов, проявляющихся большой интерес к русской культуре, истории и литературе. Теперь стало ясно, что здесь находится разрешение загадки эмигрантов: как сочетать национальную стихию, тоесть русский дух, и всемирную стихию,тоесть, стремление к проявлениям самых разных культур. Как мы знаем, Пушкин был и глубоко национален и вполне всемирен. Напомним пророческие слава Достоевского: «Если бы жил он (Пушкин) дольшеDrag. Seljana, может быть, явил бы бессмертные и великие образы души русской, уже понятные нашим европейским братьям, привлек бы их к нам гораздо более и ближе, чем теперь, может быть успел бы им разъяснить всю правду стремлений наших, и они уже более понимали бычась, чем теперь» [2].

Горячее желание профессора Оцупа воспитать на французской земле специалистов в области русской культуры и литературы исполнилось. Он оставил сплоченную группу русистов, которые, в свою очередь, передали любовь к своему предмету новым поколениям. Среди них можно назвать Жорж Нива (Georges Nivat), одного из лучших знатоков русской культуры во Франции. Оцуп понимал, что его миссия, наконец, помочь французам, изучающим русский язык, читать стихи Пушкина без перевода. Поэзия, как музыка, выше всех барьеров:

Душа моя душе учеников

Восторг живого братства сообщает

Не приобщением к чужой культуре,

А вестью, что чужсого в мире нет. [3]

К сожалению, обстоятельства не позволили Николаю Авдеевичу в полном мере реализовать себя как педагога: его университетская карьера началась относительно поздно и оказалась короткой. 28 декабря 1958 г. он скончался . Преждевременная смерть (ему исполнилось 64 года) отняла его у тех, кто был привязан к нему и многому мог от него научиться.

В заключение хотелось бы сказать, что судьба поэта Николая Оцупа ясно показывает, что, несмотря на потрясения 1917 г., русская литература осталась единой и нерушимой, где бы она ни создавалась.

1 Н. « Дневник в стихах », op.cit. стр213

\section{Список литературы:}

2 Ф.М. Достоевский, «Пушкин», Собрание сочинения, том десятый, ГИХЛ, Москва, 1958, стр. 459.

3 Н. Оцуп, «Жизнь и смерть», op.cit. стр. 165, 